\title{
COMMON LAW EQUITY IN A CIVIL LAW COUNTRY
}

\author{
AH Angelo* and Ashleigh Allan**
}

This article serves to introduce an aspect of current research related to the review of the Seychelles Civil Code and the important question of the role of trusts. The Civil Code is based on the Code Napoléon and has therefore no provision for the trust of English law. The Courts of Seychelles have, however, a statutory equitable jurisdiction. That jurisdiction has given rise to the question whether the trust of England may be able to operate in Seychelles. The prime area of discussion of this possibility has been in relation to the property rights of the parties to a failed concubinage relationship. This article focuses on that discussion.

\section{INTRODUCTION}

The story for Seychelles began in 1810. Seychelles was till then part of the French Empire. After the capitulation of the French forces in Mauritius, ${ }^{1}$ Seychelles as part of Mauritius began a new life as the British colony of Mauritius. As part of the protection for the "Religion, Laws, and Customs" guaranteed by the Capitulation, ${ }^{2}$ the Code Napoléon was retained. ${ }^{3}$ The years that followed 1810 saw the development of the inter-relationship of the French law with the Common Law of the colonial administration and its judicial system.

* Professor, Faculty of Law, Victoria University of Wellington.

** BA/LLB(Hons), Barrister and Solicitor of the High Court of New Zealand, Law Researcher.

1 The capitulation took place in 1810. The military government of the British continued till 1815 in accordance with the terms of the Capitulation. British sovereignty was confirmed by the Treaty of Paris 1814 and implemented in Mauritius by Proclamation in 1815. That Proclamation confirmed that the French laws of Mauritius were to continue "in their full force and vigour".

2 Acte de Capitulation, art 8: "Que les habitans conserveront leurs Religion, Loix, et Coutumes" as reproduced in Les Constitutions de l'Ile Maurice (Mauritius Printing Co Ltd, Port-Louis, 1962) at 79.

3 It had been extended to Mauritius by Arrêté of 1808. 
The basic provision for any Chancery-like jurisdiction of the courts of Seychelles is s 6 of the Courts Act: ${ }^{4}$

The Supreme Court shall continue to be a Court of Equity and is hereby invested with powers, authority, and jurisdiction to administer justice and do all acts for the due execution of such equitable jurisdiction in all cases where no sufficient legal remedy is provided by the law of Seychelles.

This article considers the parameters of this section and whether it can be used by the courts of Seychelles to introduce the Common Law trust. Part II considers the continuing judicial debate on this question in the context of property rights of parties to a failed concubinage ${ }^{5}$ relationship. Part III discusses references to trusts in Seychelles legislation and how the courts may interpret them. Part IV supports the commonly held view that the Common Law trust could not operate as such within the conceptual framework provided for property by the Civil Code of Seychelles.

\section{WHAT THE CASES SAY}

Section 6 of the Courts Act has in practice generally been limited to procedural matters and remedies and the courts have consistently denied that s 6 could support the application of the substantive rules of the trust.

There have been exchanges between the Supreme Court and the Court of Appeal on the scope of s 6 of the Courts Act. These exchanges have arisen in the context particularly of property between partners to a relationship of concubinage when their relationship has broken down. Relationships of concubinage are common in the Seychelles. ${ }^{6}$ The Matrimonial Causes Act provides for distribution of property upon marriage breakdown, ${ }^{7}$ but there is no comparable legislation for relationships of concubinage. This has required the courts to consider how the laws of Seychelles can assist concubins in this situation, invoking consideration of the role the equitable jurisdiction might play. Notwithstanding the social statistic, the cultural and religious focus is very clearly on marriage. A consequence of this is that the social hardship created for relationships of concubinage by the

4 The original provision was s 7 of the Seychelles Judicature Order in Council 1903. It was incorporated into local legislation in s 5 of the Courts Ordinance Cap 43 (1964). See for a similar colonial precedent the New Zealand provision in s 16 of the Judicature Act 1908, confirming the equitable jurisdiction of the High Court of New Zealand as set out in s 5 of the Supreme Court Act 1860.

5 The technical French term for the situation of a man and woman living together as man and wife. Commonly in Seychelles referred to as living en ménage. In New Zealand law they are de factos.

6 The Population and Housing Census 2010 shows 24.6 per cent married couples and 19.3 per cent cohabitating but unmarried couples.

7 See Matrimonial Causes Act, s 20(1)(g): The Court may:

make such orders, as the Court thinks fit, in respect of any property of a party to a marriage or any interest or right of a party in any property for the benefit of the other party or a relevant child.

The regime is one of separation of property. 
current law has not been addressed by legislation. The current Civil Code review project will address the matter because of its social impact and because of the equality provisions entrenched in the Constitution. The matter may well be addressed in legislation relating to property rights or social protection, rather than by reference to the law on matrimonial property.

A convenient starting-point for a consideration of the equitable jurisdiction enquiry is the judgment of Sauzier $\mathbf{J}$ in Hallock $v$ d'Offay. ${ }^{8}$ The parties lived in concubinage for 27 years. The respondent separated from the appellant, leaving her in a house with their two sons. The house was on a plot of land registered in the name of the respondent. The respondent brought an action against his two sons, claiming possession of the house and land, and an injunction restraining the defendants from resisting his occupation. The appellant intervened in the suit and sought a declaration that she had a share in the house and land. The respondent offered to give the appellant a share in the house and land, but the parties could not agree on the value of the shares. The Supreme Court found that the appellant was not entitled to any share in the respondent's house and land under the principles of unjust enrichment ${ }^{9}$ or société de fait. ${ }^{10}$

The salient features of the unjust enrichment claim are that the claimant has suffered a detriment, that the defendant has enjoyed a benefit, that the detriment and the benefit are linked, and that there is no legal basis for the benefit enjoyed by the defendant (for example the benefit did not flow from a sale or a gift). The action in unjust enrichment is a default action; it can be used only where there is no other remedy available for the detriment the claimant has suffered. A successful claimant will be awarded a monetary sum equal to the lesser of the detriment suffered and the benefit gained. By comparison with the declaration of a constructive trust in the common law in a situation similar to that of those in a broken de facto relationship, the successful claimant has no right in specific property and essentially is left with a debt claim. This is again different from the law relating to parties to a dissolved marriage who in Seychelles, by virtue of legislation, can have orders made in respect of specific property.

$8 \quad$ Hallock $v$ d'Offay (1983-1987) 3 SCAR (Vol I) 295.

9 Article 1381-1 of the Civil Code of Seychelles:

If a person suffers some detriment without lawful cause and another is correspondingly enriched without lawful cause, the former shall be able to recover what is due to him to the extent of the enrichment of the latter. Provided that this action for unjust enrichment shall only be admissible if the person suffering the detriment cannot avail himself of another action in contract, or quasicontract, delict or quasi-delict; provided also that detriment has not been caused by the fault of the person suffering it.

10 The concept of a société de fait distinguishes a commercial relationship from a social one (an association). This presumes the parties were in a relationship concerning property with an intention to advance a common interest and to share in the profits and losses involved. Maintaining a private life together would not constitute a société de fait for the purposes of property division. 
On appeal from the decision in Hallock $v$ d'Offay, the Court of Appeal ${ }^{11}$ upheld the Supreme Court's findings and the appeal was dismissed. The Court of Appeal unanimously rejected the appellant's alternative argument that the English doctrine of constructive trusts should apply because: ${ }^{12}$

it is generally accepted that the law of trusts has no place in Seychelles, so that any attempt to equate

man and mistress with husband and wife on the basis of a constructive trust seems doomed to fail.

Eric Law and Goburdhun JJA suggested legislative change to protect the interests of concubins. ${ }^{13}$ In Sauzier J's often cited dissenting judgment, he supported the appellant's argument that the Supreme Court could use the wide equitable powers under the Courts Act to administer justice by equitably distributing property where a relationship of concubinage had broken down, as no sufficient legal remedy is provided by the law of Seychelles. ${ }^{14} \mathrm{He}$ considered the current remedies (société de fait, action de in rem verso, and enforcement of a civil obligation) inadequate and that if the courts declined to use the equitable powers in this situation there would be a denial of justice. ${ }^{15}$ His judgment gives guidelines for the use of the equitable powers; the equitable powers were in addition to and not in derogation of the other powers of French law. ${ }^{16}$

Shortly after deciding Hallock $v$ d'Offay, the Court of Appeal again considered the place of trusts and Equity in Seychelles law in Monthy $v$ Esparon. ${ }^{17}$ The parties had lived in concubinage for 15 years. The respondent claimed a share in the house and shop on land owned by the appellant, as she had helped to run the shop. The Supreme Court ${ }^{18}$ had relied on the English case law on constructive trusts to make an order granting the respondent a share of the property. The Court of Appeal was divided. On the issue of trusts, Mustafa P said: ${ }^{19}$

11 The final court of appeal in Seychelles.

12 Hallock $v$ d'Offay, above $\mathrm{n} 8$, at 301, 305 and 313.

13 At 301 and 305.

14 At 314

15 At 315

16 At 317

17 Monthy v Esparon (1983-1987) 3 SCAR (Vol II) 12.

18 At first instance and prior to Hallock v d'Offay's being decided in the Court of Appeal.

19 At 19. Article 1371 of the Civil Code of Seychelles states:

Quasi-contracts result from purely voluntary acts of a person. They give rise to duties towards a third party and sometimes to mutual obligations between two parties. 
I doubt if the judge was right to rely on the principle of constructive trust in making the award. I would prefer to base my decision on the fact of a de facto partnership somewhat in terms of the provisions of article 1371 of the Civil Code of Seychelles.

Eric Law J did not comment specifically on the Supreme Court's use of the constructive trust, and queried whether unjust enrichment (which had been pleaded) could be applicable in this case. Nevertheless he found compensation could be awarded to the respondent based on the principle of Dora's case that where a concubine renders services additional to those normally rendered by a concubine, the concubine is entitled to recover for lost salary. ${ }^{20}$ Sauzier $\mathrm{J}$ reiterated the comments he had made in Hallock $v$ d'Offay: the Supreme Court should not have relied on constructive trusts to make the orders, as "[t]he English law of trusts does not apply in Seychelles and there is no need to refer to the technical and limitative principles of such law". ${ }^{21}$ Because no remedy was available in Seychelles law (société de fait, unjust enrichment, or the enforcement of a civil obligation), "[t]he learned trial Judge was entitled to use the powers under s [6] of the Courts Act to rectify the situation". 22

For a number of years after these decisions Sauzier J's comments were largely disregarded in case law. The judgments on concubinage and the division of property applied the principles of unjust enrichment and quasi-contract strictly, and were silent on the place of Equity. In Dodin v Malvina, ${ }^{23}$ the Supreme Court surveyed the authorities and expressly disagreed with Sauzier J's dicta on the court's equitable powers.

The 1998 Court of Appeal decision of Vel $v$ Knowles provided an opportunity for a reconsideration of Sauzier J's dissenting comments. ${ }^{24}$ The parties lived in concubinage for more than 17 years. The appellant was the registered owner of land, the funds for which were provided by the respondent. The appellant obtained a loan to build a house on the land, and the respondent made substantial financial and building contributions to the house. The appellant sought possession of the house and a declaration that she was the owner of the house and land. The Court of Appeal stated that: "The jurisprudence in Seychelles has evolved in an equitable way to provide relief for parties who live in concubinage. ${ }^{25}$ The Court further said that despite Dodin v Malvina: ${ }^{26}$

20 See Dora v Curator of Vacant Estates (1963) SLR 66.

21 At 27.

22 At 28 .

23 Dodin v Malvina (1990) SLR 288

24 Vel v Knowles SCA 41/1998, 42/1998, LC 136, 13 August 1998.

25 At 5 .

26 At 5-6. 
... in view of the readiness of the Courts to provide relief for "unjust enrichment" it is likely, on occasion arising, for the Courts to reconsider the reasoning of Sauzier $\mathrm{J}$ in his dissenting judgment in the Hallock $v$ d'Offay case ...

The respondent was granted a right of retention and compensation based on art 555 of the Civil $\operatorname{Code}^{27}$ and the applicant was denied possession of the house.

Again for a number of years the courts considered concubinage separation cases without referring to Equity. In the March 2012 decision of Magnan v Desaubin, ${ }^{28}$ the Supreme Court considered a case where the parties had lived together in concubinage for 35 years in a house built by the defendant on land owned solely by the plaintiff. The parties separated and the plaintiff sought orders to evict the defendant from the house, to exclude the defendant from the property, and a declaration that the defendant had no claim in the house. The Court noted that concubinage creates no legal rights and that relief can be obtained only on the basis of unjust enrichment under art 13811 of the Civil Code, and that could not be made out in this case. The application was allowed under art 555 of the Civil Code following Vel v Knowles, the Court finding that parties in concubinage are entitled to relief under art 555 of the Civil Code if the conditions set out in that article are fulfilled. At the end of the judgment, the Supreme Court indicated support for a wide interpretation of the Supreme Court's equitable powers: ${ }^{29}$

I hasten to add that even if article 555 of CCS may not be applicable it would be sufficient to ground this decision in the doctrines of equity as it would be inequitable for the plaintiff to evict the defendant without compensation for the improved value that the defendant has brought to this property with the permission and consent of the plaintiff.

In Monthy v Esparon, the parties jointly purchased a house and lived in concubinage for three years until the relationship ended. ${ }^{30}$ The Court of Appeal began by commending Sauzier J's use of equity in Hallock $v$ d'Offay: ${ }^{31}$

Sauzier J in his landmark decision of Hallock $v$ d'Offay (1988) 3 SCAR 295 attempted to bring justice to the situation even when the property was not held in joint ownership. A shame it was that his was a dissenting judgment.

27 Article 555 of the Civil Code of Seychelles regulates the situation where one person builds on another's land. The owner of the land can require the removal of the structures, or may elect to retain the structures on paying the third party either the increased value of the land or the cost of the materials and labour.

28 Magnan v Desaubin SSC 1/2011, CM3 9, 29 March 2012.

29 At [22].

30 Monthy v Esparon SCA 29/2010, CM3 16, 13 April 2012. Note the parties are different from the parties in Monthy v Esparon, above n 17.

31 At [3]. 
The Court of Appeal quashed the Supreme Court's judgment, which had ordered that the plaintiff was entitled to sole ownership of the property and that the defendant was entitled to compensation from the plaintiff in settlement of the defendant's share in the property. The Court of Appeal held that s 6 of the Courts Act provides that Equity is available only when no other legal remedy is available. The Court indicated three options available under the Civil Code for a joint owner who did not wish to remain in indivision. As the plaint was not an action based on any of those options, but on Equity alone, the Court of Appeal found the trial judge had acted ultra vires by making a property division order. The Court ordered the Registrar of Lands to restore ownership of the property to both parties and the respondent to pay the appellant damages and compensation. Whilst the Court of Appeal cited Sauzier J's dissenting judgment with approval, ${ }^{32}$ the effect of this judgment is to restrict Equity to situations where there is no other cause of action. Equity will rarely if ever be available for concubins seeking property division orders, as in most cases an alternative remedy can be found in unjust enrichment or quasi-contract.

A few months later, in a matrimonial property decision, the Supreme Court in Chetty v Lepere seemingly responded to the above Court of Appeal decision. ${ }^{33}$ The ex-wife claimed the exhusband's half share in land be transferred to her, so that she could have sole ownership. The petition was dismissed in limine, because the Matrimonial Causes Rules had not been complied with, and because there was insufficient evidence. At the end of the judgment, the Court noted obiter that if the judgment were appealed the declaration should not be found ultra petita, as the Court had an unfettered discretion to make an order under s 20(1)(g) of the Matrimonial Causes Act, ${ }^{34}$ and: $:^{35}$

It is also pertinent to note that this Court has jurisdiction to make any order as it thinks fit, in relation to matrimonial properties in exercise of its equitable powers conferred by section 6 of the Courts Act, in the interest of justice, irrespective of the fact, whether the issues were alive before the Court or not in respect of any determination it makes in relation to those properties.

These comments were restated by the Supreme Court in Dijoux v Dijoux,${ }^{36}$ another matrimonial property decision. The petitioner sought a declaration that the land and matrimonial home registered in the parties' joint names belonged to both in equal shares, and an order that the respondent compensate him for his half share so the respondent could become the sole owner. The Supreme

32 It is to be noted that art 5 of the Civil Code of Seychelles provides: "Judicial decisions shall not be absolutely binding upon a Court but shall enjoy a high persuasive authority from which a Court shall only depart for good reason."

33 Chetty v Lepere SSC 127/2007, 30 July 2012.

34 See above $n$.

35 At $4-5$.

36 Dijoux v Dijoux SSC 49/2005, 30 January 2013. 
Court cited case law to the effect that the court may use its equitable powers under s 6 of the Courts Act, in addition to jurisdiction from statute, ${ }^{37}$ to make property orders in the interest of justice. ${ }^{38}$ The Court attributed the shares of the property based on the parties' financial contributions to the house -80 per cent to the respondent and 20 per cent to the petitioner. The Court then determined that the respondent was entitled to sole ownership of the property and the petitioner entitled to compensation, based on an equitable analysis similar to that carried out by the Supreme Court in Esparon v Monthy. ${ }^{39}$

These exchanges suggest that the Supreme Court is willing to extend the equitable jurisdiction to do justice, while the Court of Appeal limits remedies available to persons in concubinage relationships to those in the Civil Code and particularly to those relating to quasi-contract and unjust enrichment.

The different approaches can be explained by different interpretations of the phrase "where no sufficient legal remedy is provided by the law of Seychelles" in s 6 of the Courts Act. Sauzier J took a broad view that the current remedies used to protect concubins were never intended to do this and they are inadequate. This thinking is reflected in the recent Supreme Court decisions. The Court of Appeal has adopted the narrower interpretation that the court is precluded from using s 6 when any remedy is available. There may however be cases where quasi-contract, unjust enrichment or art 555 cannot be made out and the Court of Appeal will use s 6 to provide an equitable solution.

The current approach of the Court of Appeal would suggest that s 6 allows the exercise of an equitable jurisdiction of a French style ${ }^{40}$ and the acceptance of English equitable measures such as injunction, but excludes the introduction of any substantive provisions from Equity.

\section{THE TRUST IN LEGISLATION}

Also part of the legal scene, but not considered in the context of s 6 , are references to the trust in bankruptcy and companies legislation, ${ }^{41}$ the offshore trust legislation, ${ }^{42}$ and in an increasing number

37 See for example Matrimonial Causes Act, s 20(1)(g). See above $n 7$.

38 See Mathiot v Mathiot SSC 105/1994; Florentine v Florentine SCA 4/1990, 12 April 1991; Renaud v Renaud SCA 48/1998, 22 April 1999.

39 But subsequently quashed by the Court of Appeal. See Esparon v Monthy SSC 436/1998, 7 October 2010; Monthy v Esparon, above n 30.

40 The Equity of England is different from the equité of French law. Equité is a notion of limited import (because it runs counter to notions of certainty in the law and the separation of powers between judge and legislator). It can, particularly in family law matters, have a corrective function in relation to the strict application of the law; in other areas it may supplement the law.

41 Bankruptcy and Insolvency Act, Companies Ordinance. Both of British colonial origin.

42 International Trusts Act. Without domestic operation and probably not a Common Law trust. Compare Maurizio Lupoi Trusts (Cambridge University Press, Cambridge, 2000) at 264. 
of other Acts in the commercial law field (which have been drafted based on international precedents). ${ }^{43}$ From the context, it is clear that the drafter (though not the Seychelles legislator) was thinking of the English Common Law trust. There is no known litigation on the meaning of trust in these specific commercial contexts. What meaning a court might give to the provisions is unclear. A court might treat them as giving rise to a fiduciary duty and, in some cases, to statutory challenges and criminal sanctions. Alternatively a court might ignore the reference to trust in these Acts as drafting errors or oversights, or translate the reference to the Seychelles legal context by interpreting trustee to mean fiduciary. ${ }^{44}$ The Seychelles judges, who have mostly been trained in the English Common Law and therefore have a non-French law background, may take the word trust in the mixed jurisdiction to mean what it says and interpret trust as an English trust.

\section{THE TRUST AND THE CIVIL CODE}

The question is whether the Civil Code system supports the introduction of the Common Law trust. If the courts adopted a wide interpretation of the equitable powers in $\mathrm{s} 6$ in a concubinage situation, or if the courts interpreted references to the trust in legislation to mean the English Common Law trust, the result may be stalemate - there is no legal infrastructure to support a trustbased judgment.

The Civil Code is the common law (droit commun) of the system. The result is that whereas a New Zealand or English lawyer goes back to precedent for core principle, lawyers in the French tradition find the core principles in the Civil Code.

In the field of property, the system is one of clausus numerus - the only types of property known to the system are those enumerated in the Code. There can be horizontal splitting of ownership of a

43 For example the use of the word trust is referred to in the Merchant Shipping Act, the Limited Partnerships Act 2003, the Trade Marks Decree, the Registration of Business Names Act, the Status of Married Women Act, the Securities Act 2007, and the International Business Companies Act. Another example is the use of "real" and "personal" in respect of property (for example the Seychelles Investment Act 2010). These are readily seen as synonyms for immovable and movable, though at the level of detail there may be differences.

Other examples of Common Law ideas in Seychelles legislation are provided by references to consideration for contracts, though in the Code there is no requirement of consideration (for example the Excise Tax Act 2009, the Foundations Act 2009, and the Seychelles Petroleum (Taxation) Act 2008). The Common Law conceptualisation makes it necessary to have separate rules for gifts and for third party benefits. In the Code system both of these are covered by the general rules of contract. The references to consideration may be seen as a drafting aberration. Some Code contracts do require exchange of value (for example sales, transfer of land, and the rules relating to lésion). These statutes will likely be read as imposing a value criterion in respect of the particular property transaction that is, no change in the basic conceptualisation of contract or in the underlying principles of the system.

44 That is no split of ownership - the fiduciary is by statute the full owner with fiduciary duties for example to the bankrupt's creditors and to the bankrupt. See arts 815-835 of the Civil Code of Seychelles. 
property right; there is no vertical splitting ${ }^{45}$ because inter alia there was no history of a Court of Chancery.

The Civil Code system can provide for an in rem action by a beneficiary against a third party acquirer from a fiduciary. This is by way of exception to the general principle of l'apparence ${ }^{46}$ and of the indivisibility of rights. ${ }^{47}$ Fiduciary duties are created by contract or by statute. ${ }^{48}$ The ability to follow property - an in rem action as distinct from an in personam action - depends on notice given by registration or implied from the nature of the relationship. ${ }^{49}$

The Code system generally favours creditors of the fiduciary and the security of transactions. The underlying principle is that of l'apparence and an aversion to secrecy. In order to protect a beneficial interest against the world at large publicity is needed..$^{50}$

45 The property right with an owner at law and an owner in equity. See FH Lawson, AE Anton, L Neville Brown (eds) Amos and Walton's Introduction to French Law (Oxford University Press, London, 1967) at 99:

There can be no distinction between legal and equitable estates. Either a person is owner or he is not; he cannot be owner for management purposes without also being owner for purposes of enjoyment. In this sense the unity of ownership is a fundamental principle of French law. It makes the peculiar English technique of the trust impossible.

46 See Encyclopédie Dalloz "Civil" Vo "Apparence" May 2009 at [11]-[15]. This provides a rule of public policy which addresses a situation where the apparent legal condition does not represent the real legal position. It is what can be known to be the legal situation without the necessity of extensive research. It is a principle which can allow judges to give priority to the facts over the law.

47 See Aubry et Rau Droit civil français vol IX at [574] as cited in Christian de Wulf The Trust and Corresponding Institutions in the Civil Law (Etablissements Emile Bruylant, Bruxelles, 1965) at 117:

Le patrimoine est, en principe, un et indivisible comme la personnalité meme, non seulement ... en ce que la meme personne ne peut posséder qu'un seul patrimoine, mais encore en ce sens que le patrimoine d'une personne n'est pas, à raison de sa nature incorporelle, divisible en parties matérielles ou de quantité, et n'est meme pas susceptible, à raison de l'unité de la personne, de se partager en plusieurs universalités juridiques, distinctes les unes des autres." [Patrimony is, in principle, one and indivisible as is personality itself, not only ... in that one and the same person can have only one patrimony, but also in the sense that the patrimony of an individual is not, by reason by its incorporeal nature, divisible into physical parts or by way of quantity, and it cannot even be, because of the unity of the person, divided into several legal entities, which are distinct one from another.]

Clear support for this is found in art 2092 of the Civil Code of Seychelles: "Whoever personally incurs an obligation shall be answerable with all his movable and immovable property, present or future, for its performance."

48 For example, child and guardian.

49 For example those dealing with a husband were on notice as to the existence of the possible protected rights of the wife as a secured creditor under the marital property regime.

50 Somewhat analogous would be the situation were a trust to be written and registered. 
On the other hand secrecy is a feature of the trust, and a trust can be created informally and orally.

Literally s 6 is supplemental to substantive law. It does not suggest an alternative or new substantive law. For concubins there is substantive provision in the law on quasi-contract. A constructive trust cannot be an alternative or new answer to the need. The quasi-contract actions are in personam. A constructive trust if available would, in a Common Law country, provide a backdated property right and an in rem action. In the Seychelles situation it could give rise only to an in personam action. As to the quantum of relief available under each action, there may be little difference - the property value that A contributed to the property which is in B's name, as compared with the value of the property of A which has been transferred to B without legal basis. ${ }^{51}$

At base a trust in Seychelles would have to be construed as a personal fiduciary relationship between the fiduciary and the beneficiary without any split in ownership or access by the beneficiary to the property by way of an in rem action. This is because the underlying principles of the system favour openness over secrecy and transparency of property ownership. The Code property regime with its emphasis on l'apparence and l'unité du patrimoine focuses on wider property interests ${ }^{52}$ and protection of transactions in the market place. ${ }^{53}$ By contrast virtues of trust are its secrecy and that it can and does deny apparent ownership. ${ }^{54}$

The trust can be seen as selfish in the sense that it protects the settlor's wishes or interests in respect of the property. It reflects a focus on the settlor's ownership.

The answer to the question of whether trusts can operate in Seychelles must be no ${ }^{55}$ conceptually they do not work in the Civil Code system. ${ }^{56}$

51 For example the transfer was not a sale or a gift by A to B.

52 Compare the succession interests of the close family - which New Zealand seeks to deal with by the exceptional legislation of the Family Protection Act 1955.

53 For example those dealing with the person whose name is on the ownership document are dealing with the full owner. The same principle is evident in art 2279 of the Civil Code of Seychelles: "With regard to movables, possession in good faith establishes a presumption of ownership."

54 The Code admits an in rem action by a beneficiary as an exceptional matter where the holding of property by the fiduciary is a matter of public knowledge.

55 Agreeing with A G Chloros Codification in a Mixed Jurisdiction (North-Holland Publishing Company, Amsterdam, 1977) at 12:

the English trust simply does now fit into the law... it would be unwise to assume as one may be tempted to do, that in Seychelles it is possible to create legal and equitable relationships.

56 Declaration of a constructive trust as sometimes mooted would amount to a judicial property order of the kind made under s 20(1)(g) of the Matrimonial Causes Act for marriage partners. There would be a direct transfer of ownership rather than a splitting of ownership. 
The unity of a person's property holding is in effect the creditor's assurance of the debtor's substance. Exceptions to the rule in French law have been few and statutory. In 2007 after a long evolution, France introduced the fiducie into the Civil Code as arts 2011-2031. This addition to the Code was an attempt to provide a "trust" for France in order to stem the flight of investment capital to London. It is clear that the fiducie is not a trust. It is equally clear that the precise nature of the fiducie in the French legal framework is uncertain, as is the extent to which the basic concepts of property are affected by it. ${ }^{57}$ There is no statutory system for the trust in Seychelles; a fortiori a trust cannot operate in Seychelles.

\section{CONCLUSION}

Seychelles' mixed jurisdiction provides an opportunity to consider the relationship between the Civil Law and the Common Law heritage and whether the English trust may fit into this. The courts of Seychelles may be tempted to use the equitable jurisdiction in s 6 of the Courts Act to protect the property rights of concubins or to interpret references to the trust in legislation as meaning the Common Law trust that judges are familiar with.

If the courts interpreted the word trust to mean the English trust then s 6 of the Courts Act becomes less of an obstacle and more of a bridge between legal cultures and to the substantive addition of the trust. If however the Court can go so far as to interpret and apply trust as an English trust, there is no reason why the use of s 6 may not be thorough-going and include all the Chancery law. The result paradoxically would then be to confirm that the trust does not fit in the Civil Code regime because the Code is based on the principle that the person identified as owner is the full owner.

57 For general discussion of these matters see M Grimaldi "Introduction of the Trust into French Law" (2011) 2 Revue de droit Henri Capitant; L Bibaut "La fiducie face au trust" (22 June 2011) Le petit juriste <www.lepetitjuriste.fr>. 